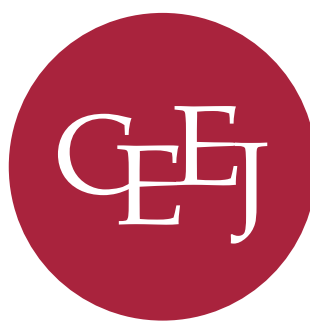

Central European

Economic Journal

ISSN: 2543-6821 (online). Journal homepage: http://ceej.wne.uw.edu.pl

\title{
Basic income guarantee in the perspective of institutional economics
}

Michał Pawłowski

To cite this article: Pawłowski, M. (2019). Basic income guarantee in the perspective of institutional economics. Central European Economic Journal, 6(53), 86-107.

DOI: 10.2478/ceej-2019-0004.

To link to this article: https://doi.org/10.2478/ceej-2019-0004 


\title{
Central European Economic Journal
}

\author{
Michał Pawłowski ${ }^{1}$
}

1 University of Warsaw, Krakowskie Przedmieście 26/28, 00-927, Warszawa, Poland, corresponding author: michal.andrzej.pawlowski@gmail.com

\section{Basic income guarantee in the perspective of institutional economics}

\begin{abstract}
The main problem of this article is the basic income guarantee in the perspective of institutional economics. The author evaluates theoretical literature considering the topic and discusses past empirical research. The predicted and the actual outcomes of the programme are compared and synthesized using the New Institutional Economics framework. Hence the basic income guarantee is presented as a social policy proposition, and also as an institution in the meaning of this branch of economics. Originality of this approach relies on the novel use of institutional tools in the discussion considering the problem, mainly in the context of the empirical and theoretical results' comparison.
\end{abstract}

Keywords: the basic income guarantee, institutional economics, social policy, inequalities

JEL Codes: E02, H55, J08

\section{Introduction}

"The basic income guarantee“ (BIG), "the universal basic income“ (UBI) or simply "basic income“ refer to an idea or a postulate used to implement a universal social benefit, provided to every citizen, regardless of their salary or their willingness to work. Defining it generally (specific descriptions are given in following sections), one might say that fundamental assumptions of the postulate are its unconditionality, universality (diversely viewed - should also the immature or pensioners obtain the service, or only people in the productive age?) and its modest size ("basic"). The implementation of the programme would, according to its proponents, increase social security, provide a more even and just income distribution in a given economy or be an effective alternative to current social services. The basic income guarantee could become a remedy for the specific problems of contemporary free-market economies, namely negative side-effects of globalisation and of a quick technological development, which often causes anxiety and a feeling of instability.

Despite the strong bounds with contemporary context, this idea has its long tradition. First such postulates reach even the tuarn of XVIII and XIX centuries and writings of Thomas Paine (Munger, 2015a, pp. 485-488). Simultaneously, very intriguing are the intellectual roots of the basic income's supporters: most of them refer to the left-wing social and economic thought and to liberal traditions (especially based on John Rawls' Theory of Justice), or even the libertarian. In search of arguments for the proposition, they inspire not only with thinkers in kind of J.K. Galbraith, but also even Milton Friedman.

The purpose of this paper is to present an original approach to the topic, including discussion both of the theoretical literature and of the empirical attempts (unfortunately, relatively scarce) and an assessment of possible economic outcomes and presumable dangers of BIG taken as an institution. More detailed questions 
include this institution's influence on the labour market and the level of income inequalities, as well as its interaction with other institutions. The theoretical predictions are compared with the empirical results and elaborated with a use of institutional framework. The task is significant due to many reasons: first, the problem clearly anchors in both the contemporary and the historical disputes considering the society and economics. Second, only virtually do in this case opinions cleavages go along the lines between liberals and socialists, "Austrians" and Keynesists or free-market's supporters and interventionists. As Friedman's proposition of the negative income tax proves, these are only labels and not always accurately refer to the reality. It suffices to see the basic income as an intriguing topic. But more surprisingly, the problem still has not been thoroughly discussed or tested. Too often it functions only as a curio from other countries (eg, Swiss referendum).

The issue is evaluated in the perspective of the institutional economics. This means that an important element of the paper is its interdisciplinarity, but the emphasis is put on the economic aspects of the problem. Due to the scarce empirical data, the character of the paper is mostly theoretical, but there is scope for the evaluation of the BIG (or similar) experiments, for instance, Alaska Permanent Fund, the tests with the negative income tax, or the Iranian basic income. A very significant element is the basic income guarantee's evaluation as an institution interacting with the society and market.

Methods used here include an array of tools referring to the institutional economics, like institutional approach to the issue of labour market, public finance and chosen macroeconomic factors. Also some philosophical arguments are used, yet very narrowly. First, a theoretical framework concerning the BIG is presented and compared with empirical data. Having been characterized as an economic institution and described in regard to the literature, the BIG is investigated in its connection with other institutions. This means, it is enquired how it can influence future institutions and reshape the current as well, or how the latter affect the basic income's results.

Section 1 considers the basic income's description as an institution in the understanding of the institutional economics. Its institutional character is labelled and the programme is located in the framework proposed by various authors, among others Acemoglu and Robinson (2010). In Section 2, the fundamental assumptions of the BIG are shown (with a detailed explanation of hopes and fears of its proponents), as well as different modes of implementation. It is explained what influence is expected basing on the literature, and several arguments and counter-arguments are introduced. Section 3 considers previous experiments and attempts to implement the basic income, such as Alaska Permanent Fund or Iranian universal payment and Section 4 provides an institutional evaluation of the proposition both as a social and economic policy tool and, most important, as an institution, through gathering conclusions of the empirical part together with the findings of the theoretical section. These results, as well as conclusions from previous sections, are recapitulated in a short paper's summary.

\section{Section 1: Basic income as an institution}

Institutional framework used here consists of propositions by Douglass North, Daron Acemoglu and James Robinson, Olivier Williamson and Stefan Voigt. According to the classical definition of institutions, formulated by North (1992, p. 4), they are "the rules of the game of a society or more formally are the humanly devised constraints that structure human interaction". He also differentiates the formal institutions, like legal rules, from the informal, for example customs, and mixed ones. The question of whether "rules" and "constraints" can be treated as synonyms, in other words, if phrases "formal rules" and "informal constraints" are only contingent connections or rather reveal some essential bounds, I will leave here as marginal (it is more broadly discussed by Hodgson (2006, pp. 8-13)). Of course, institutions might be defined many-fold: abovementioned Hodgson claims that they are "systems of established and prevalent social rules that structure social interactions" (Hodgson, 2006, p. 2). The definition proposed by North has been chosen, as it offers a quite reliable equilibrium between its generality and accuracy.

Acemoglu and Robinson (2010) add a typology of institutions regarding their object: economic and political. Williamson (2000) proposes a hierarchy of institutions: 
from the first, most basic level, which includes customs, traditions, religion (embeddedness), changing in time period from 100 to 1000 years; through second level of institutional environment, consisting of substantial legal rules, like property rights, changing between 10 and 100 years; third layer of governance (concrete policies and solutions: changes averagely 1 to 10 years); to, finally, constant allocation of production factors. The last here used framework is proposed by Voigt (2013), who divides institutions into internal and external, regarding mechanism of their execution, Internal institutions, at least to some extent, automatically define the mode of their application. External, on the other hand, must be supported by the state intervention. Beside that, Voigt also mentions de iure and de facto institutions, namely those, which function only theoretically and actually (it does not stay, of course, in the contrary).

Describing the basic income guarantee in general, it would be a universal, yet with some possible restrictions (eg, only to adults), unconditional, considering the work or income, benefit of a minimal size. Taking a step back to the previous definition of institutions, it is justified to claim that the universal basic income is an institution, First, there is no doubt that this postulate might be implemented only as a result of human actions. Second, this solution would influence one's behaviour, by creating new incentives and constraints. These incentives would be economic: one may presume the effect to be a change in population's expenditures, affecting, for example, consumption (possible rise). They could also result in diminishing of labour supply in economy, whereas constraints would influence enterprises and the public sector, by marking out a new framework of their behaviour. Regarding these, and also a different income distribution in the society, BIG would create new structures of human interactions, new "rules of the game". It could function parallelly as a constraint and as a rule. From a citizen's point of view, implementing the basic income would entail a new right, a right to receive the defined payment, and, on the other hand would create an obligation: a constraint put on the administration forcing it to supply a permitted person with the basic income and respecting their right to it.

It seems clear that, taking North's framework, BIG would be a formal institution. The reason to say so is the fact that a necessary condition of creating it can only be a legal action, in most countries a parliamentary act. It would play a significant role in a legal system, quite differently than customs or traditions. It is also uncontroversial that BIG might be treated as an external (imposed by the state) institution (Voigt) and de iure. Leaving aside some a bit more specific cases like country's bankruptcy and a following lack of capacity to fulfil its legal commitments, basic income guarantee undoubtedly could be a de facto institution.

Apart from that, the guarantee would be an economic institution, considering the framework proposed by Robinson and Acemoglu. Referring to a schema proposed by these scholars, political institutions result from the distribution of political power (both de iure and de facto) and affect only the distribution of de iure power in the future period. Economic institutions, on the contrary, being effects of the same factors, influence future economic results and income distribution. The basic income guarantee institution would not have impact on the political de iure power (eg, tasks of constitutional authorities), but would create a different, comparing to the status quo ante, production share and by its incentives and constraints could change a total income in the economy. Thus, it is a sensible assumption to regard it as an economic institution, even if one must remember that it also implies an indirect influence on other chain links: income distribution results in political de facto power equilibrium, which, together with de iure power, shapes political and economic institutions. Having shown that, a trial to reveal possible effects of basic income guarantee is made in next sections, with a big use of this schema.

Last, but not least, it is worthy to analyse BIG from the point of view proposed by Williamson. It can surely be said that the universal basic income would be a part neither of first, nor fourth institutional level, namely a slowly and spontaneously shaping custom or religion and constantly flowing resources' allocation. However, it is not so obvious to determine, whether it would belong to the second level of institutional environment, or rather the third level of governance. At first, it seems far more reasonable to describe it as a third-level institution, since it is exactly there, where legal processes directly shaping the market and economy take place. To the second level, 
on the other hand, belong much more general rules, including constitutional acts defining the groundings of judiciary system or parliament's competencies. But there is also place for the property rights here, as for the fundamental rules of whole economy. Trying to define the basic income guarantee as a second- or thirdlevel institution, one must previously find a convincing description of this institution's significance. One may assume, for example, that it would just be a modern social programme, replacing all others and then decide that it rather belongs to the third level. But it is also possible to consider BIG as a revolutionary change inside the market system, as important as a change in the basic property rights (like, for example, the transformation from the planned socialist economy, with a very small space for the private property, to the free market system) and, consequently as a sheer fundamental of the economy and state or maybe BIG is to be found somewhere between these two levels.

A different position of the basic income guarantee means a different influence of the institution. In case of declaring its belonging to the second level (institutional environment), it would shape particular policies described by Williamson as the governance. These policies could simultaneously - by a sort of a feedback change the strength of this influence. Meanwhile at the level of governance, due to the same feedback it could to some small extent reshape the superior institutions, but most of all would impact the resources allocation. This is the reason for which I am prone to consider BIG as a third-level institution, but one must remember, that the question still lays open.

To summarize, it is possible to present a set of characteristics of the basic income institution. First and foremost, it would be a formal, external, de iure and in most cases also de facto institution. Second, economic - and thus impacting economic results and the income distribution and also indirectly the political power distribution. Provided that BIG were a concrete economic proposition, it would affect resources allocation and to some small extent superior legal (eg, constitutional) rules, and in case of regarding it as an institution belonging to this very superior level (what is also possible) BIG would shape particular solutions from the level of governance and - as a matter of feedback - it could also impact first-level institutions, embeddedness.
These conclusions: institutional character of the basic income guarantee and its properties as an institution allow to make use of the tools offered by institutional economics. This, as well as the analysis of the assumptions made behind the proposition of the universal basic income, its proponents' motivations, their inspirations, is the topic of Section 2. As these problems have been already partially described, it might seem as a small step back. But it is not a repetition, but a reference and a following expansion.

\section{Section 2: Theoretical framework}

As mentioned before, one of first BIG-like solution proponents was a British liberal, Thomas Paine. It is worthy to start this section with a presentation of his view, as it might, despite its old-fashioned form, reveal some core assumptions correlated with the idea.

Paine called for a disposable payment of 15 pounds sterling for everybody turning 21 years old, regardless of their income or estate, and for an unconditional income of 10 pounds for all those who are above 50 years old (Munger, 2015a) ${ }^{1}$. Undoubtedly relevant were the circumstances: French Great Revolution was close to its end and the Industrial Revolution in England has just begun, bringing as a side-effect rise of apprehension among unskilled workers, fearing the loss their jobs. Paine proposed financing the payment from a special fund. What makes it intriguing, a predicted source was not a capital tax (ie, machines), but a land tax instead. According to Paine it was to make up for a lost good, common in the state of nature, which is land. This idea was a straight consequence of a belief typical for this age, that it is the main production factor (significantly resulting with the David Ricardo's system), but also of a deeper philosophical thought, that appeared in social philosophy with John Locke's theory of social contract.

For Locke, a moral justification of property rights for a given area, is the work put in land's cultivation. As long as a man gathers the fruits of the earth, without cultivating it, he has no right to it. But in a moment when his force

1100 years earlier, in $1688,52 \%$ families had to live on 25 pounds sterling of year income and $83 \%$ - below 50 pounds. 
of labour is enduringly connected with some certain piece of land, when this production factor enriches the field with an additional value, he gains exclusive right to use it. It is so, because he is the owner of the labour that became fixed to the land (Zwolinski, 2015).

This is why, as formulated by Paine, every land owner owes to other members of a society part of his rent. Actually, his property rights stem from inextricable bounds of labour who transformed it to land, but on the other hand, he thus excludes the others from the use of it. This lost entitlement to natural production should somehow be compensated.

A very similar view is what today characterises basic income proponents. Of course, there is no need to speak about land, since factors with far bigger productivity are capital or human capital. However, as Paine regarded the land as a common good and demanded an equal (at least to some extent) share of it, nowadays such common good is total product in an economy. From that point of view, created income requires its redistribution, obviously partially limited, because individual labour is still fixed to other factors.

This formulation of the old idea intuitively entails a claim that a payment offered to the community should be unconditional regarding somebody's work, namely independent from gained income and from the question if they work at all or not. Of course, several other economic arguments are also proposed.

A first group of such arguments is made of arguments being essentially rejoinders to a frequent objection to basic income guarantee that this programme would significantly diminish incentives to take on a job. It appears that it might be even conversely. In his paper, Bryan (2005) draws a comparison between BIG and social funds reforms in the USA in 1996, namely changes in the Earned Income Tax Credit (EITC) and creating the Temporary Assistance for Needy Families (TANF). Since then a fundamental condition to obtain social service is being employed. This obligation, as Bryan points out, may result with suboptimal market solutions coming from particular actors' decisions: they might be prone to start worse paid, less demanding jobs, or even discourage their home dwellers to start a job at all (families, not individuals, do have a right to this payment) (Bryan, 2005, pp. 598-599).

The programme also generates other strong work disincentives. EITC divided people enabled to the service into three income groups: phase-in, where every earned dollar was subsidized with \$0.4 payment (maximal income at the level of $\$ 10020$ ), next (up to $\$ 13$ 091) with a constant support of $\$ 4008$ and the last, phase-out, below the income threshold of $\$ 32121$ (for a comparison, annual average income in the USA was \$45 802 in 1996 (OECD Data, 2018). In this group, for every earned dollar the payment fell with $\$ 0.21$. Consequently, a supported person with an income within phase out is "punished" for their work. Apart from this $21 \%$ quasi-taxation, when one considers all other forms of taxes, it might appear that the effective marginal taxation rate was driven to $50 \%-60 \%$ (Bryan, 2005, p. 599). It would not be such a big problem, if not the fact, that in 1996 about $64.5 \%$ of supported households belonged to the phase-out group. Thereby, most of EITC beneficiaries obtained strong work disincentives. Considering other social services, like food stamps, a labour supply optimal for a given household may diminish even more, affecting negatively aggregated labour supply (Bryan, 2005, p. 608). To these objections, Bryan also adds numerous doubts about severely excluding demographic or social conditions that must be fulfilled by families willing to get the support.

It appears that BIG omits these problems. Implementing a universal social programme, stipulated with no concrete requirements, eliminates negative effects stemming from the fall of support rate and thus erases work disincentives. Moreover, as Barbara Surdykowska points out, the universal basic income could even increase labour supply: such system would not demotivate people who could lose social support in case of starting a slightly better-paid job, At the same time, for many it would be an incentive to find a wellpaid (what means: highly rated by market), but unstable job, making it much more attractive comparing to stable, yet small income (Surdykowska, 2006).

On the other hand, having listed out the positive sides of the basic income guarantee, Bryan also points out some drawbacks of this proposition, of which the most significant are predicted costs. Moreover, due to the elimination of earlier mentioned support fall rate, the number of recipients compared to the number of net payers would only increase, raising the amount of money required to implement the solution. In this situation, tax increase would probably be inevitable, but one must remember that taxation is also considered a negative factor to labour supply (Bryan, 2005, p. 608). The whole 


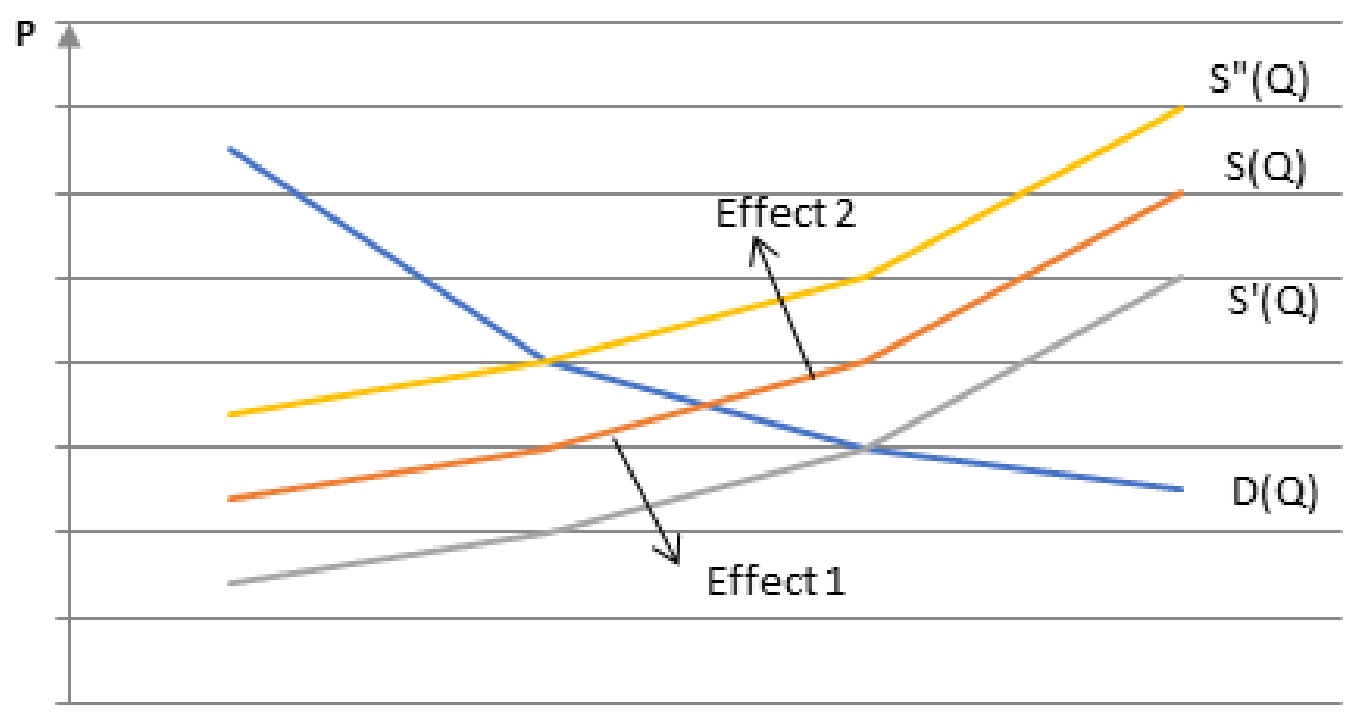

Graph 1. Two BIG's effects on labour market. Source: own elaboration.

context reveals hardships bounded with predictions of feasible consequences of the basic income guarantee on labour market: without concrete data it is impossible to estimate the influence of two main effects: one of them is decrease caused by quitting a job (or at least diminishing number of working hours) by some market actors, who will be supplied with an unconditional payment and will have to face higher tax rate; second is an increase resulting from the elimination of labour disincentives, present in some current social services, and the support of other, less conventional, forms of employment. As authors of an OECD report considering possible forms and effects of BIG state, the influence on job incentives might strongly vary depending a market structure. Some workers will get disincentives with a given prices level (what, by the way, will improve their negotiation position to their employers), others - mostly the endangered by some consequences of BIG - incentives (OECD, 2017, p. 7). Effect 1 presented on the Graph 1 shows positive job incentives and Effect 2 negative. One cannot a priori estimate which one of them will prevail and if the position of the $S(Q)$ (labour supply curve) might be closer to $S^{\prime}(Q)$ or rather $S^{\prime \prime}(Q)$. Such estimation needs an assessment of possible BIG costs and an interpretation of more concrete data.

The OECD report (2017) might be somewhat helpful. The authors present simulation of a possible basic income scenario for every chosen country. Following the assumptions of the model, BIG would be equal to the current level of social expenditures in a given state, would be received only by people below the retirement age (also at an exogenic level) and given to individuals, instead of households. At the same time, other social services and tax-free allowances would be abolished, however some public in-kind services, like free education would be still kept (only if they have been already functioning). Also some special services devoted to particular groups, for example, the disabled population would still apply. These assumptions are just an approximation, since obtained solutions differ between OECD countries.

Statistics (OECD, 2017, p. 3) presented by authors unambiguously show that a simple replacement of social services by BIG (primarily without the assumption of tax-free allowances abolition) keeping the budgetneutrality and then distribution of these sums among the society (below the retirement age) could not probably be successful: such basic income guarantee would averagely be only about $20 \%$ poverty line for a given OECD country. Willing to achieve positive BIG effects, shown by its proponents, taxation rise, increasing the government debt or tax-free allowances abolition would probably be a required step. The last means is, as mentioned a moment before, an assumption made by 


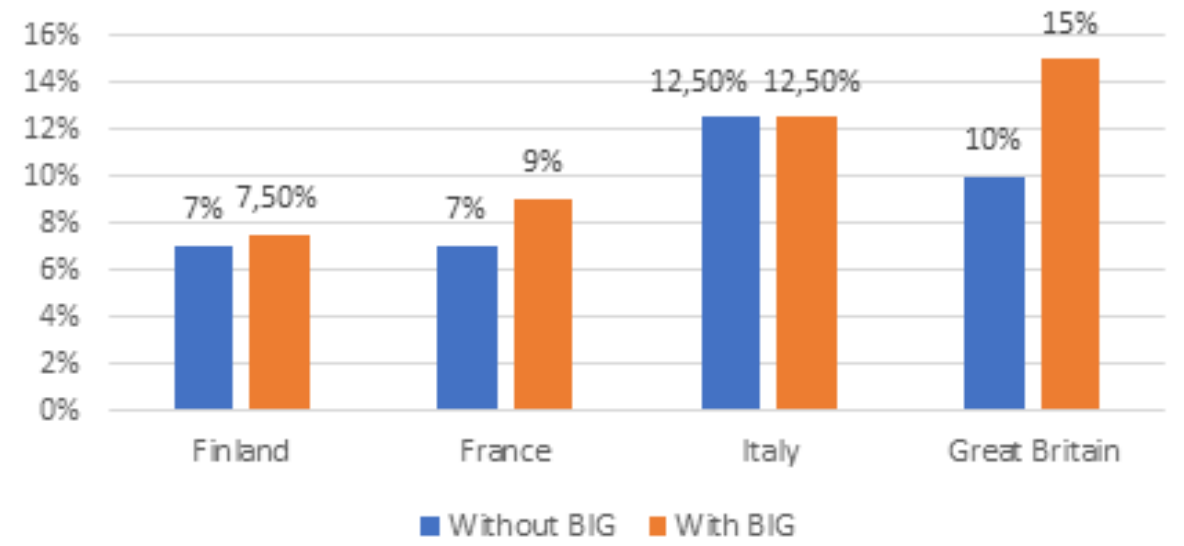

Graph 2. Poverty level currently and after implementing the basic income guarantee. Source: own elaboration* based on: OECD (2017). Basic Income As a Policy Option: Can it add up?. Policy Brief on The Future of Work, OECD Publishing. On line. Access 06.02.2018. https:/ / www.oecd.org/els/emp/Basic-Income-Policy-Option-2017.pdf * The graph is only an approximation of a table present in (OECD 2017). Its exact model would require repeating the whole simulation, as the authors present in the report only approximated bars.

Tab. 1: Monthly basic income guarantee per capita equal to current aggregated social services and tax allowances

\begin{tabular}{llll}
\hline & Adult & Child $(<18)$ & Poverty line for an individual \\
\hline Finland & $€ 527$ & $€ 316$ & $€ 1074$ \\
\hline France & $€ 456$ & $€ 100$ & $€ 909$ \\
\hline Italy & $€ 158$ & $€ 158$ & $€ 737$ \\
Great Britain & $£ 230$ & $£ 189$ & $£ 702$ \\
\hline
\end{tabular}

Source: Elaboration based on: OECD (2017). Basic Income As a Policy Option: Can it add up?. Policy Brief on The Future of Work, OECD Publishing. On line. Access 06.02.2018. https://www.oecd. org/els/emp/Basic-Income-Policy-Option-2017.pdf.

the authors of the report in its following pages. Thus, as stated in the report, an inseparable part of universal basic income implementation would have to be deep changes of tax systems, what is clearly presented on more detailed examples of Great Britain, Finland, France and Italy.

Table 1 reveals that with an assumption of budget-neutrality, basic income guarantee would be substantially lower than the individual poverty line. Of course, it is a core point of this proposition to provide only with a basic income, but there is an important question whether such a small amount of money can be sufficient. Following the results of the simulation, BIG payed to the adults would be equal to the level of $49 \%$ of poverty line in Finland, 50\% in France, 32\% in Great Britain and only $21 \%$ in Italy. A hypothesis that such a solution would work only in countries already providing their citizens with a big level of public support ${ }^{2}$ and that taxation rise is inevitable, seems justified.

However, even without a taxation change BIG would strongly influence income distributions in societies: some income groups might lose, others may gain. According to OECD predictions, the most significant gains of universal basic income implementation would be among the middle class - especially in France in Finland. In Great Britain and Italy slightly worse-off groups could gain, but to some extent it can be explained with a small share in current programmes (OECD, 2017 , p. 5). Despite this fact, in mostly all four countries poverty rate would rise (even though its risk would be more evenly distributed). It stems from the fact that with the assumption of a simple replacement the social services by BIG, the same sum of money which was previously divided among the poorest, now would be used to support every individual. A next table presents it (Graph 2).

In Great Britain, the poverty rate would presumably increase from a given $10 \%$ to $15 \%$, in France from about $7 \%$ to $9 \%$, in Finland from $7 \%$ to $8 \%$ and only in Italy would not change, staying at the level of $13 \%$. It results

2 Although Finland and Italy seem to provide a similar level of social services (about 30\% GDP in both) (OECD 2016), it is easily visible that in fact Finland offers a way bigger support: in Italy an average aggregated social payment is equal to $20 \%$ of poverty line, whereas in Finland to 40\% (OECD 2017, 3). 
from the abovementioned fact that Italy provides quite a small level of social services. Consequently, the hypothesis that BIG, with here undertaken assumptions, might achieve its goal, proposed by Bryan (2005), namely poverty reduction, seems unjustified. Completing this task would only be possible with a huge change of tax system, what by the way is also proposed by this author (Bryan, 2005, pp. 608-610).

Despite it, BIG proponents present many other advantages to be achieved by such a programme. These values are not easily quantifiable (and with a lack of data not quantifiable at all), but one should not ignore it. First, as slightly mentioned before, current social services are very often ineffective and expensive. Matt Zwolinski points out that in the US (on the federal and the state level together) about one trillion dollars is used every year to fight poverty (Zwolinski, 2015, p. 515). At the same time big part of this sum must be spent on purely administrative and control tasks. This is caused by the need to prevent malpractices (such as granting the support to those not having right to it). If this sum was simply distributed among the needy ones, each of them would get about $\$ 20000$, an amount equal, or even bigger than the annual poverty level (also about $\$ 20$ 000) (Bryan, 2005, p. 507). The next point is that such formal requirements and controls might frequently be oppressive or even humiliating. This logic supports the basic income proposition: the programme, through its egalitarianism and universality could not lead to a social exclusion and stigmatization of its recipients.

BIG seems advantageous comparing to quite different social services, like food stamps (Munger, $2005 b, p .505)$. Such a programme is ineffective, as it does not maximize the utility of its recipients. They receive a stiff market basket, not a definite amount of money. Apart from the risk of a growing black market (illegal stamps trade), the budget solutions beneficiaries end up with are not optimal (Varian, 2010, pp. 29-31).

One of last BIG's characteristics, especially important because of some parts of a following analysis, is its role as an element of public finance. Munger (2015b) states that it would be a kind of a negative head tax. An analogy with a negative income tax, proposed by Milton Friedman (discussed later), is clear. A main advantage of a head tax - easiness to collect it - is also important here, although the direction is opposite: everybody would receive the payment. Munger proposes that every citizen, regardless of their age would be supplied with the basic income. This would not involve illegal immigrants, to not increase the risk of uncontrolled migration flood. The basic income would be taxed, in order to diminish work disincentives. According to Munger it is possible to adjust the public finance and the resources allocation in the economy so that taxes increase will be very slight. It is shown on two graphs, the first presenting a possible income-tax situation in a five-person society, the second in the same society after implementing the BIG. Assumptions (arbitrary) of a primary model are: $0 \%$ taxation for income below $\$ 16000,20 \%$ between $\$ 16000$ and $\$ 100000$ and 30\% above. Moreover, everybody earning less than $\$ 16000$ receives a sum making his income equal to this level.

It must be noticed, that in the situation 1 it is very probable that person 4 will very quickly quit their job, if they earn below \$16 000 and the government compensates income to this level. In the situation 2, after implementation of the BIG, free-tax allowance is abolished and any income above $\$ 100000$ is taxed with a 32\% rate. Despite significant increase in government's expenditures, the balance between state costs and incomes is only slightly changed. Persons 2, 3 and 4 have noticeably gained with the BIG implementation, person 1 has slightly lost, and only the situation of person 5 has got significantly worse. This thought experiment confirms the OECD predictions, that, perhaps, paradoxically the poorer part of population loses with BIG implementation, even assuming some tax changes.

Considering the fiscal consequences of BIG it is worth presenting the dangers that might follow its implementation, presented by Henderson (2015). He comments on numbers shown by the BIG proponents, especially in the context of Zwolinski's proposition. The latter, apparently, was to indicate in a mail correspondence with Henderson a sum of $\$ 10000$ yearly as an adequate level of the universal basic income in the USA. Henderson points out that it is absolutely impossible: the number of potential recipients (only regarding adult citizens of the USA) is about 206.8 million people. Multiplying it by $\$ 10000$ comes to 2.068 trillion dollars yearly. Taking 1 trillion dollars as a size of current social services, about 1 trillion needs 
Tab. 2: Work and welfare - a possible situation 1

\begin{tabular}{|c|c|c|c|c|c|}
\hline & Gross Income & Tax & Transfers & BIG & Net Income \\
\hline Person 1 & $\$ 500000$ & $\$ 136800$ & $\$ 0$ & $\$ 0$ & $\$ 363200$ \\
\hline Person 2 & $\$ 200000$ & $\$ 46800$ & $\$ 0$ & $\$ 0$ & $\$ 153200$ \\
\hline Person 3 & $\$ 100000$ & $\$ 16800$ & $\$ 0$ & $\$ 0$ & $\$ 83200$ \\
\hline Person 4 & $\$ 10000$ & $\$ 0$ & $\$ 6000$ & $\$ 0$ & $\$ 16000$ \\
\hline \multirow[t]{2}{*}{ Person 5} & $\$ 0$ & $\$ 0$ & $\$ 16000$ & $\$ 0$ & $\$ 16000$ \\
\hline & & Together: $\$ 200400$ & Together: $\$ 22000$ & Together: \$0 & \\
\hline Governm & net revenue: \$ & 400 & & & \\
\hline
\end{tabular}

Source: Elaboration based on: Munger (2015b). One and One-Half Cheers for a Basic-Income Guarantee: We Could Do Worse, and Already Have. The Independent Review, Vol. 19, No. 4.

Tab. 3: Work and welfare - possible situation 2

\begin{tabular}{|c|c|c|c|c|c|}
\hline & Gross Income & Tax & Transfers & BIG & Net Income \\
\hline Person 1 & $\$ 500000$ & $\$ 153120$ & $\$ 0$ & $\$ 16000$ & $\$ 362800$ \\
\hline Person 2 & $\$ 200000$ & $\$ 57120$ & $\$ 0$ & $\$ 16000$ & $\$ 158880$ \\
\hline Person 3 & $\$ 100000$ & $\$ 25120$ & $\$ 0$ & $\$ 16000$ & $\$ 90880$ \\
\hline Person 4 & $\$ 10000$ & $\$ 5200$ & $\$ 0$ & $\$ 16000$ & $\$ 20800$ \\
\hline \multirow[t]{2}{*}{ Person 5} & $\$ 0$ & $\$ 3200$ & $\$ 0$ & $\$ 16000$ & $\$ 12800$ \\
\hline & & Together: \$243 760 & Together: \$0 & Together: $\$ 80000$ & \\
\hline Governm & net revenue: \$ & 760 & & & \\
\hline
\end{tabular}

Source: Elaboration based on: Munger (2015b). One and One-Half Cheers for a Basic-Income Guarantee: We Could Do Worse, and Already Have. The Independent Review, Vol. 19, No. 4.

complementing, and even more, about 1.3 trillion, since about $30 \%$ of that sum are state programmes, which could not easily and very quickly be replaced with the BIG (this payment would probably function as a federal service). It means that tax incomes need to be increased from current 2.993 trillion dollars to about 4.361, namely for as much as $45.7 \%$ (Henderson, 2015, p. 491). Because at the same time taxes decrease the taxation basis, they would have risen more than $45.7 \%$ - Henderson assumes $50 \%$ (of course not percentage points). Moreover, as taxes cause deadweight loss, it would be a next negative effect of the basic income. Henderson states that the relation of tax rate increase and a deadweight loss growth is quadratic: the $50 \%$ taxes increase raises the deadweight loss for $125 \%$ (if $D S=(D P) 2$ than $S^{\prime}=\left(1.5 * P^{\prime}\right)^{2}=2.25 *\left(P^{\prime}\right)^{2}$; $2.25 * P^{\prime 2}-P^{\prime 2}=\mathbf{1 . 2 5} * P^{\prime 2}$ ) (Henderson, 2015, p. 492). A following graph shows it (Graph 3).
At the very end - BIG is sometimes thought to be a remedy for dangerous side-effects of processes of digitation and automatization of work. In dystopian visions of the future, the humanity is to split into two groups: capital owners, gathering excessive gains from the work of robots, who has crowded out most of humans from the labour market, and the destitute masses of proletariat, counting on their mercy. The basic income would guarantee them dignified life. But these anxieties seem to be far-fetched. Similar fears took place many times before in human history and, by now, the experience did not confirm them (vide luddites). It might be so also this time. Current predictions do not show that this is the future awaiting out societies. Despite an OECD (2016a) report which presents that about 9\% of jobs is endangered with disappearance, and among jobs requiring only lower secondary degree even $40 \%$, 


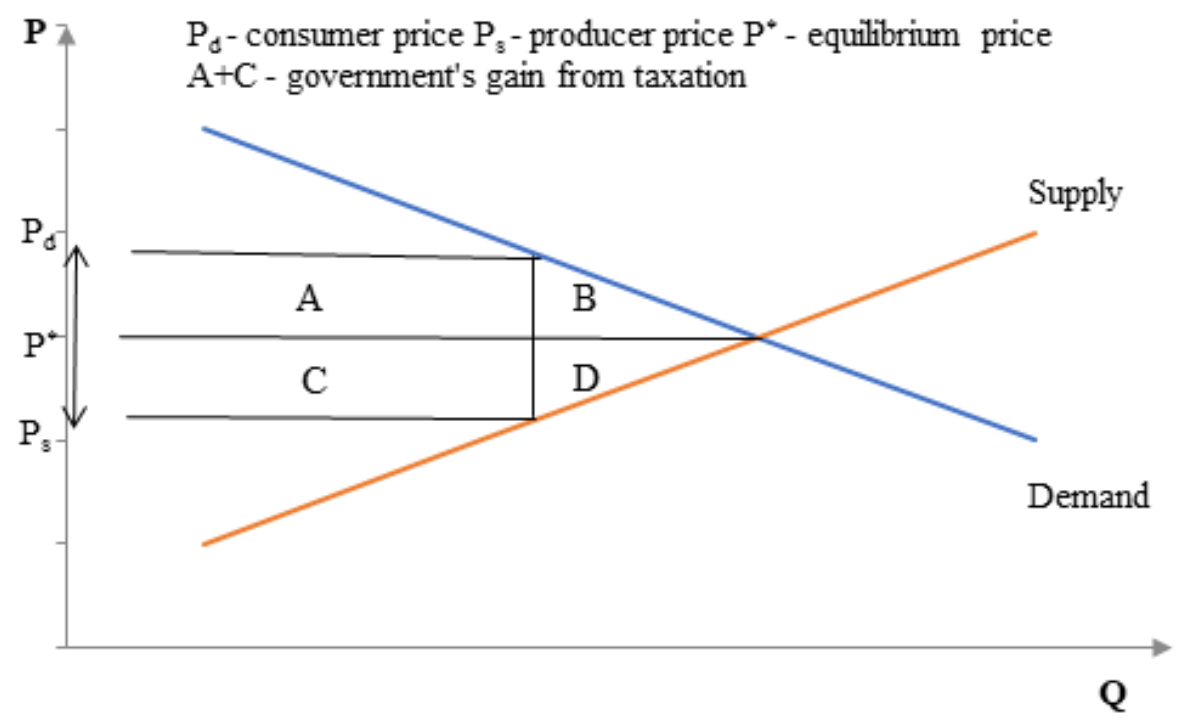

Graph 3. Deadweight loss caused by taxation. Source: own elaboration based on: Varian (2010). Intermediate Microeconomics. A Modern Approach. Eighth Edition. W. W. Norton \& Company, New York, London, 305.

Tab. 4: Influence of the basic income guarantee

\begin{tabular}{ll}
\hline Predicted positive effects & Predicted negative effects \\
\hline It might increase work incentives (Effect $1^{\#}$ ) & Might increase work disincentives (Effect 2) \\
\hline As a cash transfer much more efficient than in-kind & In case of keeping budget-neutrality a very small size of a payment \\
\hline Will increase stability on labour market & A bigger payment requires tax increase $\rightarrow$ a work disincentive \\
\hline Lower administrative costs than in current programmes & Higher taxes $\rightarrow$ a bigger deadweight loss \\
Less exclusive and humiliating for recipients & After BIG implementation the needy might loose \\
\hline
\end{tabular}

Source: Elaboration based on literature quoted in the section.

\# "Effect 1" and "Effect 2" refer to possible BIG effects on labour market, presented on Graph 1.

it must be remembered that new technologies causing disappearing some particular jobs also generate the new ones. Moreover, such changes will not be sudden (among others due to the need to adjust legal norms, etc. to new conditions) and there is also a chance that they will lead to a decrease of a required workload, not to job losses by the employees. Of course, all of these will need new policies easing the negative side-effects and helping to increase work mobility, retraining and perhaps raising social security as well. Especially in the context of the last remark, there is a place for implementing the BIG, but it might be achieved also with some other different tools, maybe more efficient.

Positive and negative results of BIG, mentioned in the literature, may be presented as follows:
After this preliminary theoretical part, considering characteristics of the basic income guarantee, there is time to start an analysis of tests and trails of its implementation and of similar programmes.

\section{Section 3: Empirical results}

An issue of this section is an analysis of particular trials of BIG implementation and tests considering the payment or to some extent similar programmes, which may due to this resemblance show important empirical characteristics of the universal basic income. The section starts with a presentation of the negative income tax and Alaska Permanent Fund. Then some experiments (eg, in India) are discussed and at the very end an evaluation 
of a de facto BIG in Iran is made. The subject literature is in many points contradictory and vague, so only well evidenced examples of basic income guarantee (or of similar programmes) have been chosen.

The negative income tax is here presented owing to a significant convergence with BIG: the basic income would precisely function as a negative, even though head, tax. A basic assumption of negative income tax - a solution whose the most widely known proponent was Milton Friedman - is a minus tax rate in a defined range. It means that for a given limit $\mathrm{L}$, income I $(I<L)$ and a tax rate $\mathrm{t}$, a government supplies a citizen with $t^{*}(L-I)$. The size of the payment might be also described as $G-t^{*} I$ (where $G=t^{*} L$ ), which means that the state pays a minimal guarantee that is successively diminished with every earned dollar for $t$ (Moffit, 2003, p. 121). With the second notation the resemblance of negative income tax to basic income guarantee is only more vivid.

In the United States, four experiments considering possible effects of negative income tax have been conducted between 1968 and 1982. \$225 million total has been spent (1984 prices) and an aggregated sample form all tests involved 8746 families (that is them, not individuals, that has been provided with such experimental support). Tests differed regarding geographical and race section, upper income limit (from 1.5 to 3.25 of poverty line, which was equal to \$10 610 in 1984 for a four-member family), tax rate (0.3 to 0.7 or even changeable comparing to income in the last research), size of guarantee $(0.5-1.4)$ and grant breakeven level ( 1 to 3 of poverty line). In the fourth experiment, research lasted for different samples 3, 5 or 20 years, in others 3 (Robins, 1985, pp. 568-573). The results has shown a significant labour supply slump (with an exception of some particular groups - eg, black married men in New Jersey (first test) or white women living in the countryside (second test)), but what is especially interesting are aggregated results with a division to four social groups: husbands, wives, single female heads and youths.

The biggest percentage fall of worked hours' number may be noticed within groups of youths and wives (taking the absolute numbers also slightly in case of single female household heads). These two groups were affected with the strongest percentage negative change of employment. The statistics seem intuitional.
Tab. 5: Labour supply changes due to the negative income tax

\begin{tabular}{lcccc}
\hline & \multicolumn{2}{c}{ Worked hours (yearly) } & \multicolumn{2}{c}{ Employment rate } \\
\hline Husbands & -89 & $(-5 \%)$ & -0.3 & $(-3.5 \%)$ \\
\hline Wives & -117 & $(-21.1 \%)$ & -0.6 & $(-22.5 \%)$ \\
\hline Single female heads & -123 & $(-13.2 \%)$ & -0.7 & $(-15.7 \%)$ \\
\hline $\begin{array}{l}\text { Youths } \\
\text { In parentheses percentage change }\end{array}$ & -173 & $(-22.2 \%)$ & -0.9 & $(-20 \%)$ \\
\hline
\end{tabular}

Source: Elaboration based on: Robins (1985). A Comparison of the Labor Supply Findings from the Four Negative Income Tax Experiments. The Journal of Human Resources, Vol. 20, No. 4, 567-582.

Tab. 6: Average substitution and income effects from all four experiments

\begin{tabular}{lcccc}
\hline & \multicolumn{2}{l}{$\begin{array}{l}\text { Substitution effect } \\
\text { (for } \mathbf{\$} / \mathbf{h})\end{array}$} & \multicolumn{2}{l}{$\begin{array}{l}\text { Income effect } \\
\text { (for } \mathbf{\$ 1 ~ 0 0 0 )}\end{array}$} \\
\hline Husbands & 45 & $(0.08)$ & -25 & $(-0.10)$ \\
\hline Wives & 101 & $(0.17)$ & -22 & $(-0.06)$ \\
\hline Single female heads & 78 & $(0.13)$ & -55 & $(-0.16)$ \\
Substitution and income elasticities in parentheses & \\
\hline
\end{tabular}

Source: Elaboration based on: Robins (1985). A Comparison of the Labor Supply Findings from the Four Negative Income Tax Experiments. The Journal of Human Resources, Vol. 20, No. 4, 567-582.

Labour supply fell most significantly among those, whose earnings are only poorly correlated with their living standard (so-called second earners). In case of first earners, namely people having the biggest input into household's budget, the fall is slighter. Using the available data, Philip Robins has also calculated in his research the substitution and the income effects. Average results present as follows:

As Robins points out, positive substitution effect and negative income effect are consistent with the predictions here. It means that the $\$ 1000$ rise of an average husband's income results in his labour's decrease for 25 hours yearly. In the same group 1 dollar per hour increase in the salary prolongs the working time for 45 hours a year. Analogous phenomena can be presented with a use of elasticities (parentheses), which shows percentage change after the rise or fall of income/ salary for $1 \%$. It is apparent, that income effect prevailed, since in an opposite situation labour supply fall would not be indicated, as it was proved in Table 5 . 
A different, quite an unexpected effect of negative income tax, detected in the last experiment data, was a significant increase of divorce rate. Keeley (1987), basing on his regression shows that a multiplier of the divorce number equals 1.51 for black populace, 1.60 for white and 2.09 for Latino (for marriages above the level enabling to the support), comparing with analogous control samples (variables significant). Moreover, below the income limit these values are 1.54 for black people and 1.51 for white ones. At the same time a correlation of the tax rate and divorce number is positive (for white insignificant) and the influence of guarantee is negative (significant only for Latinos).

These slightly surprising observations might be easily explained. Assuming the theory of rational subjects maximizing their utility, and remembering that the payment concerns households, not individuals (even considering a multiplier for the family size) an optimal solution on a utility curve moves: gain from a possible divorce increases. For example, taking a pair, whose income is much bigger than a predicted limit, but after a divorce one of them (presumably a woman, because of statistically lower earnings) would be enabled to the support, then the alternative gain from the divorce rises (Kelley, 1987, p. 245).

To conclude that some of these problems stem from the decision to support families instead individuals, seems to be justified. But in case of negative income tax this is the only one possible solution, because in another case people who may not need providing them with a support would also get it, for example, students with low incomes, whose living standard is high thanks to their parents' earnings. This pitfall suggests some kind of superiority of programmes not requiring big additional prerequisites and conditions put on future beneficiaries and at the same time designed for individuals.

Such a payment was established in Alaska within a framework of Alaska Permanent Fund. The state, gathering most of its government's income from oil extraction strongly depends on this resource's price fluctuations. There are only about 11000 employers in the sector (comparing to total Alaska's population of 500000$)$, but it is responsible for $85 \%$ governmental revenues (Brown \& Thomas, 1994, pp. 38-39). At the same time, because of the natural conditions, many tasks that local administration must undertake, are significantly more expensive than in other states of the United States. In order to increase budget stability and diminish fluctuations' influence to it, the Alaskan government established in 1976 a special fund, towards which, according to a constitutional amendment, goes "at least 25 percent of all mineral lease rentals, royalties, royalty sales proceeds, federal mineral revenue-sharing payments and bonuses received by the state" (Brown \& Thomas, 1994, p. 41). That money is invested: not less than $55 \%$ in fixed income securities (mostly federal government bonds), $12 \%$ to $25 \%$ in common stock in US companies, $5 \%$ to $10 \%$ in real estate, $10 \%$ in international stocks and 5\% must be invested in Alaska (Smith, 1991, p. 144). The fund was anchored at the level of state constitution. To increase its resilience to political factors, governor Jay Hammond decided to implement a transfer for Alaska's citizens, in order to decrease the popularity of using the money for current extra expenditures, which could possibly happen in the future (Brown \& Thomas, 1994, pp. 41-42). People, seeing the fund's impact on their budgets, would be less likely to support such actions.

The size of a transfer has been hovering from $\$ 331.29$ in 1984 to \$2 069 in 2008 with an average of \$1 122.04 (Alaska Permanent Fund Corporation, 2018). Every Alaska's citizen (regardless of age) gets the money in case of at least one year spent in the state, and if they plan to stay longer. About $95 \%$ of population fulfil these requirements. (Goldsmith, 2010).

As Goldsmith points out, despite the long period of the fund's existence, its effects has been only superficially investigated. In one of researches based on data from 1980-2001 it has been proved that the dividend has very slightlychangedconsumptiondecisions of thepopulation, statistically indistinguishably from other states or seasons of the year (the payment usually takes place in a last quarter) (Hsieh, 2003). The author explains it with a consistency with the life cycle hypothesis, according to which consumers strive to equalize their consumption in time. In case of Alaska it was possible, since the serviced sum has been sufficiently big, paid regularly and possible to predict in advance. This has permitted to treat it a permanent income. According to Goldsmith, the dividend has contributed to creation of additional 10000 workplaces and has dragged 15 000-20 000 new residents. Moreover, any special decrease of labour 
supply has not been noticed (however, unfortunately Goldsmith is basing on data from 1984 - just few years after implementing the permanent fund. But one must remember a serious factor restricting an explanatory role of such researches - it is not easy to differentiate the dividend's influence from the permanent fund's as whole.

Economically social impacts of the payment are visible in spite of their small share in population's budgets. The biggest of the past dividends (2008) equals to $\$ 2069$, which gives only about $23 \%$ of the poverty line for a two-person household counted in 2009 by the US Department of Health and Human Services. However, it enabled to reduce the poverty level among native Americans ${ }^{3}$ from $25 \%$ to $19 \%$ between 1980s and 1990s and Alaska itself was one of three states with smaller income inequalities at the beginning of 21st century than in eighth decade of 20th century. During that time income ratio of $20 \%$ most well-off citizens to $20 \%$ the most badly-off fell from 6.6 to 5.8 , whereas in the United State in general increased from 5.5 to 7.3 (Goldsmith, 2010, p. 12). Other possible results of the programme labour market changes either higher natality - have not been confirmed or thoroughly investigated.

In order to inquire feasible effects of the basic income guarantee, a few other tests have been conducted. Apart from earlier described experiments with the negative income tax (sometimes precepted as the BIG research (Bowman, Mallett, \& Cooney-O'Donoghue, 2017)), some trials have taken place in Canada, Australia and India.

Experiments in Canada (1974-78) and in Australia (1972-75) brought no unambiguous conclusions, as the first of them was ceased in the middle of the process, and the second because of a very small (60 families), noncontingent research sample, which was not compared with any control sample. In the Australian test, as a side-effect of the main focus, namely (hardly measurable) sense of financial independence among women (Bowman et al., 2017, pp. 11-15), also the topic of work (dis)incentives was ignored.

Another experiment has been carried on in India (Standing, 2013a, 2013b). It started in 2011, lasted 18 months and the samples were constituted by more than 20 Indian villages. Altogether, about 12 thousand people took part in the research, half of whom was receiving the

3 For other citizens Goldsmith proposes no such statistics. service - in the first series 8 villages' inhabitants were a research sample, the remaining 12 were a control group (both samples included 1 tribal village). Basic income was paid individually, unconditionally, universally. Primarily, BIG equalled to 200 rupees monthly for grown-ups and 100 for children (later on 300 and 150), whereas an average daily wage in India was about 230 rupees (India Average Daily Wage Rate, 2018).

As main results of the fund Standing (2013a, pp. 4-6) points out public health's improvement, he notices that the money was spent mostly on houses' renovations and that expenditures on alcohol and tobacco did not rise severely. Unfortunately, in most cases he proposes no concrete statistical data. He claims that in a research sample the ratio of households declaring adequacy of their income to nutrition needs was raised from $50 \%$ to $82 \%$ in the last evaluation. A vivid improvement was also noticed in the field of education. A proportion of children attending school was higher in the research sample than in the control sample for about $12 \%$, of which half of pupils attended private schools (comparing to $30 \%$ in control group).

In regard to other impacts, for example on labour market, there was no serious decrease. Actually, households supplied with the basic income guarantee raised the number of hours worked twice as often as those in the control group, and thrice as often as the latter started their own businesses. They increased their livestock for about $70 \%$, diminished debts and saved more (Standing, 2013a, pp. 6-7). Apart from the social effects, probably strongly dependent on local context, what makes it especially interesting is the increase of the labour supply and strong entrepreneurship incentives. The latter might result from increasing the financial stability due to the payment.

Recently, some other experiments have been started in Finland, Ontario, Dutch Utrecht, Oakland and even in Kenia. Since these tests still last, their conclusions remain unknown. But luckily, their authors present very diverse attitudes and declare different aims: in Finland the programme is to test the influence on work incentives, in the Netherlands also the correlation of the service and indebtedness, health and willingness to start unpaid job (eg, volunteering), in Ontario it checks the impact on the poverty level and in Oakland the main undertaken topic is technological unemployment (Bowman et al., 2017, 
pp. 22-27). Unfortunately, not all of them are flawless. For example, in Finland or in Holland a research sample has been chosen only out of social services beneficiaries (including unemployment benefits). The lack of other groups, also average employees, means that the results will be only partial.

Sometimes as a country with a real basic income guarantee is presented Brazil. De iure it is true, because in 2005 the parliament implemented a legal act constituting the universal basic income (Lavinas, 2006). However, the same act stipulates that in the first instance the poor will get any support. This norm permitted to develop other social services, conditional regarding beneficiary's income, and thus the basic income guarantee de facto does not function. But a country where the BIG has been implemented is Iran. Since December 2010 former subsidies for bread and energy costs has been replaced with equal, universal, monthly and individual payments. In time of first four months more than $82 \%$ of Iran's population has been included in the system, later on this ratio has risen to $95 \%$ (Salehi-Isfahani, 2014). The service's size was set on the level of 455000 riyals per month, which gave $\$ 42.86$ with an average 2011 exchange rate (Official Exchange Rate Iran, 2018), whereas in regard to 2009 data an average daily wage equalled to $\$ 17.41$ (purchase parity power from 2011) (Iran, Islamic Republic. The World Bank, 2018). The service covered $4.9 \%$ expenditures of the most affluent quintile and $49.3 \%$ of the most badly-off (Salehi-Isfahani \& MostafaviDehzooei 2017, p. 8). Consequently, Iranian basic income guarantee equalled about $40.2 \%$ poverty line (2012 level).

Programme's critics accuse it of having negative impact on Iranian economy by slowing down GDP growth and raising unemployment and inflation (average inflation rate in years 2010-2016 equalled nearly 20\% (Salehi-Isfahani \& Mostafavi-Dehzooei, 2017)). However, the correlation of all these outcomes is to a big extent contingent: in the end of 2011 Iran faced severe international sanctions, which were the direct cause of the economic crisis (Salehi-Isfahani \& Mostafavi-Dehzooei, 2017, p. 2). What seems here to be an effect of the BIG, namely high inflation, is mostly a result of setting up the service's size on a far too big level in regard to state budget's constraints, and later on of a quite careless policy of reprint of money, instead of reducing the income guarantee. The necessary effect was inflation's increase (Salehi-Isfahani, 2014, p. 4). The crisis had one additional, a very significant here outcome: an analysis of the basic income's impact is barely possible and might reveal causal chains only with some probability and with a big margin of error. That is why authors here cited rely on statistics mostly from 2010 and 2011 (with a use of representative data for 46517 people, where $84 \%$ are men and $16 \%$ are women).

In the given period no substantial drop of labour supply was noticed. Out of significant variables an unexpected effect of positive correlation of work hours' number and the payment's share in expenditures (intensity of treatment) was observed - coefficient 0.043 , but a coefficient measuring a correlation of unearned income logarithm and of work hours was as anticipated: -0.207 , which equals to a labour supply drop for about $0.002 \%$ for every payment's unit. Interestingly, one of regressions has shown a statistically significant negative correlation of labour supply and the BIG for the age group 20-29, whereas results are insignificant for others (Salehi-Isfahani \& Mostafavi-Dehzooei, 2017, pp. 10-26). Presumably, it stems from the fact that young people feel slighter incentives to keep their job regardless of their income. In general, these partially unexpected results might be explained (apart from the short time of investigation) by the character of the Iranian economy. Because of relevant constraints on the credit and labour markets, the payment's influence on number of hours worked might decrease comparing to the predicted by the theory. Credit constraints reduce the yield from future instalments and high unemployment diminishes the chances to find employment in case of the need to start it (or increase working time) again after quitting it (decreasing working time) (Salehi-Isfahani \& MostafaviDehzooei, 2017, p. 3).

Out of other possible effects one must distinguish an impact on poverty rate and inequalities level. The indicators used here are poverty rate (as a ratio of individuals under the poverty level), poverty gap, measuring the intensity of poverty as an average distance of the indigent's income from the poverty line and also the Gini index:

The tables show that in spite of the sanctions imposed on Iran in 2011 the poverty level has substantially dropped, even two-fold, comparing 2012 with 2009. The biggest decrease took place in countryside regions and 
Tab. 7: Poverty rate and poverty gap in Iran (percentage)

\begin{tabular}{lllllllll}
\hline Year & Poverty rate & & & Poverty gap & & \\
\hline & Countryside & Cities & Teheran & Total & Countryside & Cities & Teheran & Total \\
\hline 2009 & 13.4 & 9.8 & 6.2 & 10.2 & 4.0 & 2.6 & 1.3 & 2.8 \\
\hline 2010 & 10.3 & 7.2 & 5.6 & 7.8 & 2.9 & 1.8 & 1.1 & 2.0 \\
\hline 2011 & 6.3 & 5.2 & 2.8 & 5.2 & 1.5 & 1.1 & 0.7 & 1.2 \\
2012 & 5.0 & 5.4 & 4.4 & 5.1 & 1.0 & 1.1 & 0.8 & 1.0 \\
\hline
\end{tabular}

Source: Elaboration based on: Salehi-Isfahani (2014). Iran's Subsidy Reform from Promise to Disappointment. Policy Perspective, No. 13. Economic Research Forum, 7.

Tab. 8: Inequalities in Iran (Gini index)

\begin{tabular}{lll}
\hline Year & Expenses per capita & Income per capita \\
\hline 2009 & 0.421 & 0.414 \\
\hline 2010 & 0.415 & 0.414 \\
\hline 2011 & 0.382 & 0.367 \\
2012 & 0.375 & 0.367 \\
\hline
\end{tabular}

Source: Elaboration based on: Salehi-Isfahani (2014). Iran's Subsidy Reform from Promise to Disappointment. Policy Perspective, No. 13. Economic Research Forum, 7.

the slightest in the capital. Both the poverty gap and the poverty line reveal it. Also the income and expenditures inequalities fell significantly.

Discussed empirical cases permit to draw some conclusions regarding the basic income guarantee and the similar programmes. First, the most neutral for the labour market and a wider social context seem, basing on the negative income tax experiments, supplying with the payment the individuals, instead of the households, what can be seen as an important element of the basic income idea. The BIG may to some degree influence the equilibrium on the labour market, and if so, the most vulnerable to such (dis)incentives are so-called second earners. But particular empirical tests are not fully consistent here: the effect is the most visible in the negative income tax experiments, slightly less in the case of Iran, and the Indian experiment contradicts this hypothesis. Thus one must be careful by drawing much more general conclusions, especially when the difference between social service in various countries. Undoubtedly, the basic income decreased the poverty and inequality level even though (what can be presented as its disadvantage) that it is universal and undifferentiated respecting one's income. This is proved by Iranian and Indian examples and foremost by Alaskan, which state changed significantly from the one with the biggest inequalities to the most egalitarian one. Last, but not least, the programme has not, apparently, caused any drastic shiftss in consumers' decisions and did not result in huge unexpected changes in particular economies, apart from the mentioned before.

\section{Section 4: Institutional evaluation}

Having characterized in the first section the basic income guarantee as the formal, external, in all cases de iure and in the most de facto institution, economic and grounded in the level of the institutional environment or the governance (presumably the latter), I might move on to its evaluation. In this task helpful may be the tools of institutional economics, especially considering Stefan Voigt's suggestions.

He proposes to take a few steps by measuring the efficiency of a given institution (Voigt, 2013, pp. 15-22). The most important are: first of all, to isolate an investigated institution, later on to define actions consistent and inconsistent with it and to compare it with actual ones. This, of course, requires a sufficient time range and good value data (as "objective" as feasible). It also means that all following research and simulations must give the same results - to facilitate it, a clear standard of the one's behaviour's from an expected result is to be described - it would then be a measure of the institution. It must be remembered that institutions may coincide and render each other's influence. 
Although Voigt means institution's functioning as a kind of a constraint to possible actors' decisions, and when discussing the predicted and the actual behaviour, he speaks about rules' efficiency, it still seems to be a good direction to use his proposition in the context of the BIG. One may compare expected results of the basic income's implementation with the observed ones and also can discuss its effects as the institution from the second or the third level according to Williamson. Other features (formal, external, de iure, and nearly always de facto) are not useful in this context. One might only point out, that the peculiar case of the de iure and de facto divergence took place in Brazil, where the BIG, being mentioned in a legal act, served only as a reason to develop other social programmes, without its de facto implementation.

Thus the basic income guarantee can be viewed as a well isolated institution - a social programme that does not depend on the income or the willingness to work and that is supplied only in a small amount of money. Confusing it with other social services is rather hard, but not always are its impacts easy to present out of the context of different institutions, due to the data availability, especially the "objective" ones. In case of India the problem was a scarce amount of reliable statistics, Alaska lacked (despite the long time since the institution has been implemented) profound research considering, for example, the impact on the labour market, and the Iranian BIG is barely possible to assess because of a sudden, exogenous and prolonged economic depression, that took place just after starting the programme. Using the available tools and data, the solution is to collate the expected and the actual effects of the BIG and to reveal its connections with different institutions. So the first step of the institutional analysis will be the comparison of the basic income's influence predicted by its theorists with the empirical results.

In the end of Section 2, some possible impacts has been presented in the table. The positive ones were: work incentives, a bigger efficiency comparing to in-kind services and low administrative costs, smaller stigmatization and the stability on the labour market. The negative side of the BIG was: work disincentives, the payment's size, a likely need of tax raise (and thus the next disincentive) and deadweight loss, or a paradoxical poverty increase. Some of these features cannot fulfil the earlier mentioned requirements of the objectivity or of anchoring in reliable data, namely lower administrative costs (very hard to assess), decrease of stigmatization or beneficiaries social exclusion and the high (comparing with in-kind services) efficiency. Other surely might be useful in an institutional analysis.

It appears that only slightly have the work disincentives overbalanced the incentives. It was so in the case of experimental trials with the negative income tax (the second earners were especially vulnerable), but one must notice some differences with the basic income. In Alaska no such results has been observed, however, most important, the reason for that was the lack of good scientific investigations. In India the positive impact on the labour market was clearly visible, but this conclusions was not anchored in objective (in Voigt's sense) data. The Iranian BIG caused a small drop in labour supply only in one of the age groups, which was explained with the institutions functioning in this society and economy: very inelastic credit and labour market, to keep it short.

In none of the cases the budget neutrality has been violated and no tax raise has been needed to fund the programme. But it mostly stemmed not from the responsible policy or other institutions, but from the geographic conditions or the character of the conducted experiment. In the USA and in India, tests were granted from the external sources and in Alaska and Iran the connection with the natural resources' extraction was clear (the Iranian BIG replaced the previous food and energy subsidies). The consequence is a hindrance to estimate universal basic income's influence on public finance in "normal" conditions (eg, in a big country with a balanced and diverse economy).

The relatively small size of the payment (with the exception of NIT experiments) did not prevent from reducing the poverty level, which was a distinct result especially in Iran, moreover anchored in very reliable statistics. Thus, the hypothesis that the BIG might mostly hit the poor was falsified. In Iran it was exactly the case of replacing one social programme with the BIG, which, according to the OECD simulation would bring a noticeable rise of poverty in France, Great Britain and Finland. Simultaneously, both Alaska and Iran experienced a substantial drop of inequalities - it might have stemmed from the more even distribution and allocation of money in the economies. At the same time a 
number of other positive, but usually hardly measurable effects were observed in India.

Having been characterized as aneconomicinstitution, the BIG should be now investigated considering its bounds with other institutions. In the proposition of Acemoglu and Robinson economic institutions derive from political de iure and de facto power in a given period $t$. At the same time they influence economic results in the given period and resources distribution in the next one $t+1$. Where it was spoken not about the BIG tests but about actual actions striving to its (or of a similar service) implementation, it really was a resultant of an interplay between theoretical and practical political decisive powers (as usually in politics). An interesting example is provided by the case of Alaska, where the service was a side-effect - it was designed to strengthen Alaska Permanent Fund's durability. Coming back to the BIG's effects, it is hard to show a clear impact on economic results, mostly owing to the impossibility to isolate this institution out of others: in the negative income tax experiments and in India no macroeconomic data have been collected, in Alaska it is difficult to differentiate dividend's impact from the Fund's in general (and following investments) and in Iran an exogenous shock has taken place soon after launching the programme. With some certainty one may present the effects on the resources and income distribution in the future periods, which was proved by the fall of inequalities in Alaska and Iran. Also in the Indian experiment it was fairly visible that the households included in the research sample were successfully encouraged to save and invest more or to start their own businesses. Such changes may result (according to the used schema) with a different distribution of the de facto and de iure political power in the future.

Regardless of the above questions, there is still a problem whether the basic income guarantee institution belongs to the third or to the second level of the Williamson's hierarchy. Indian example shows that there is a significant change of resources allocation and actors' decisions, which suggests recognizing the BIG as an element of the institutional environment. However, earlier quoted research of consumers' decisions in Alaska serves as an argument for the institution's belonging to the third level of the governance, since actors behaved consistently with the life cycle hypothesis and the provided payment did not revolutionise their long-term actions. This and the fact of a clear and direct impact on resources allocation strongly suggests that the basic income guarantee is a kind of a governance-level institution. Thus, the most important is the influence on the allocation, but one must also remember about the reciprocal reaction to the shaping it level of the institutional environment.

As the possible consumer's choice range is enlarged, thanks to moving up the individual budget constraints, there is no need to provide the control of the actions that are inconsistent with the institution of the basic income. But there is still some field where the question about the BIG's enforcement is sensible, namely the problem of its legal implementation. The reluctance to it is undoubtful, what might be shown by the simple fact that the number of countries with the basic income is still incredibly small. The reasons are partially institutional and to some extent lay in popular myths about the institution. The best example proving that it is not easy to implement BIG is the case of the Swiss referendum in 2016. Only about $25 \%$ voters backed up the proposition to provide a universal monthly payment of 2500 Swiss Francs, which equalled living costs in the country (BBC, 2016). The risk of violating the institution (in case of its successful enforcement) is marginal itself, as it would mean a voluntary resignation of free payment, but (leaving out also the Brazilian case, where the institution functioned only de iure, but not de facto), in most instances it will not be unproblematic to implement it. Especially considering the needed changes of other institutions, constraining some of them.

As important as all described phenomena are the possible interactions of the current institutions and the basic income guarantee. It has been already presented that in most countries an inevitable element of the BIG implementation would be taxation system changes and dismantling (or reduction) of most of social services. So undoubted is the impact on formal institution, economic, and mostly de facto. Regarding other institutions, e.g. informal and internal, India's example proves that an effective launching of the BIG programme influences nonregulated legally spheres of human behaviour. The institution could, especially in developing countries, improve public health, hygiene and education level. Similar changes could take place considering social 
institutions, often informal, but at the same time internally enforced. Financial stability, stemming from providing a basic, yet constant payment, helps to emancipate some worse off groups, like women who are still in many countries dependent on their male family members. It is imaginable that the institution of the basic income would similarly impact the situation of youths in Spain or Italy, where the extent to which they are economically autonomous is very low, due to the bad labour market conditions and some cultural patterns. BIG could be then a strong incentive to social change. Experiments in the United States with the negative income tax have shown that even an apparently less significant problems like the question whether the payment should be supplied to individuals or households can substantially change the social structure, and indirectly maybe also demographic.

According to the Acemoglu, Robinson and also Williamson, the successful implementation of the basic income would entail a shift in the political power distribution, which could be a direct result of inequalities or poverty level drop. Beside that, some similar politically economic solutions in other life spheres could get more popular, including the problem of pension scheme. In case of positive BIG's impacts, wider acceptance could be got by postulates of the citizen's pension, whose implementation would importantly change current pension schemes. Analogously, if it appeared that after introducing the basic income guarantee gains in a given economy would be overbalanced by costs, it would serve as a counterargument against similar programmes.

Having discussed BIG's impact on other institutions, one cannot omit the topic of the reverse relation, that is of these institutions' influence on the universal basic income's efficiency. As the comparison of the empirical results and the theoretical predictions shows, it is a factor that must not be left out. Undoubtedly significant is the interaction of the BIG institution with the labour market mechanisms, which was especially vivid in the case of Iranian basic income. Owing to the institutional constraints on the labour and credit markets, the service's impact strongly differed from the initially assumed. Also the issue of the inequalities and poverty level depends on the institutional surroundings. BIG's exteriority in Iran and in India (and, to some extent, also in Alaska) falsified theoretical implications of the simulation prepared for four European countries by the OECD experts, whose predictions was that in most cases a direct effect of the basic income would be the poverty increase. The reason of this difference surely was institutional and geographical one.

Consequently, BIG's influence's strength will vary regarding the functioning of other institutions also for other (here not investigated due to the data lacks) possible effects of the programme. The gains resulting from the diminishing the control costs of the eligibility to obtain the payment would be substantially higher in the countries with lower social capital (and consequently wider acceptance of the system abuse by individuals) than in those ones, where there is also a bunch of social institutions in form of internal rules constraining such behaviours. Similarly, in states with a decent work ethic, the disincentives on labour market could be overbalanced by the incentives increasing the labour supply (namely by the bigger popularity of non-standard forms of employment). Following Max Webber's hypothesis, it could the case of Northern Europe countries.

Among all the BIG's features, the most important here are the ones stemming from the typologies of Williamson and Acemoglu and Robinson. Following Voigt's suggestions regarding the required steps of the institution's assessment (especially the principle of institution's isolation out of other and of the objectivity), one may present fallouts of the different resources' allocation (inequalities fall, marginally negative impact on labour supply). The lack of a "revolutionary" shift, both from the point of view of a state's budget or individual's actions, suggests recognizing the institution as belonging to the institutional level of the governance. However, the basic income, through its impact on formal and informal institutions might create an incentive to serious social and politically economic changes. Apart from that, another important outcome of this analysis is the observation of BIG's efficiency depending on other institutions in the environment.

\section{Summary}

The result of the conducted analysis is the characteristics of the basic income guarantee as an institution. It is the formal, external, de iure (and usually de facto, too) economic and belonging to the governance level 
institution. Thus, it affects resources allocation and their distribution, gives a feedback to the level of the institutional environment and interacts with other institutions - not only does it influence them, but also they change its efficiency.

The basic income institution tends to be not so revolutionary in the context of individuals' market decisions - in India, where it was such, this impact might have stemmed from the generally modest size of social expenditures. Main effects are changes in the income distribution and labour allocation: the fall of inequalities, small work disincentives and poverty drop were clear. The last outcome contradicted the theoretical findings, among others the ones placed in the OECD report considering the basic income guarantee. The cause of this inconsistency can be the structure of past empirical attempts: in the case of India and the USA the funds to conduct the experiments were provided externally, and in Alaska and Iran the source of the money was strongly bounded with the specific incomes in these economies, on which they substantially rest. An important advantage of the service was its simplicity, which was proved by the outcomes of the negative income tax experiments in the USA (a rise in divorce rate and a strong response of labour supply). The explanation might be differences between the negative income tax and the basic income guarantee, namely providing the households with the payment (not the individuals) and the tax rate diminishing the guarantee with the income's rising.

The positive results were achieved despite the relatively scarce size of the service: the Iranian BIG equalled about $40 \%$ poverty line, Alaskan (considering the largest dividend) $23 \%$ and in India the adult payment provided about $3.5 \%$ of an average monthly income (daily wage 230 rupees times 25 working days). It shows that the modelled by the OECD possible BIG levels for an adult individual (Italy - 23\% of the poverty line, United Kingdom - 32\%, Finland - 49\%, France $50 \%$ ) could possibly achieve their goals. But on the other hand, the character of the past experiments suggests tax rate or indebtedness increase in order to omit the presumable effect of the poverty rise, resulting from the removing current social services and replacing them only with the BIG.
Apart from that, a very important factor is the basic income's interaction with other institutions. Its influence depends on institutions regulating labour market, influencing the fiscal equilibrium of the state's budget and also on the geographical conditions. Conclusions seems justified, that the possible BIG's effects will vary regarding the social capital and informal rules and conventions in a given society. The institution itself might impact (eg, by the inequalities fall) not only the simple resources allocation, but also the political power of particular groups. The basic income solutions may thus be a strong emancipatory incentive in many places in the world and significantly reshape the social structure of a given country.

The conducted analysis joins theoretical outcomes obtained by the scholars investigating the topic of basic income guarantee with the empirical data considering the problem. Results of the theory and the actual sphere are compared and elaborated with a use of institutional framework. Consequently, the paper surpasses the limits of past theoretical inquiries or case studies and at the same time offers much more than a simple compilation of these two approaches. Using institutional theoretical tools in the case of the basic income guarantee permits to draw a far more fruitful conclusions than it would result from a simple economic analysis.

The basic income guarantee institution appears to be an efficient and a quite simple mechanism of social policy. It does not cause any radical shift in actors' market behaviours and at the same time enables to achieve desirable outcomes with quite slight side-effects. But on the other hand, it still might influence other institutions, also informal, and indirectly affect the society's and economy's shape. Despite that, to minimize the negative side of the service it would be required to provide huge amounts of money - as a consequence, the BIG seems to be an institution possible to be implemented in a still small number of countries. Undoubtedly, many problems here unsolved still needs to be answered, what is a challenge for current and future researches. 


\section{References}

[1] Acemoglu, D., \& Robinson, J. (2010). The role of institutions in growth and development. In D. Brady \& M. Spence (Eds.), Leadership and growth (pp. 135-164). Washington, DC: World Bank, Commission on Growth and Development.

[2] Brown, W., \& Thomas, C. (1994). The Alaska permanent fund: Good sense or political expediency? Challenge, 37(5), 38-44.

[3] Bryan, J. (2005). Have the 1996 welfare reforms and expansion of the earned income tax credit eliminated the need for a basic income guarantee in the US? Review of Social Economy, LXIII(4), 595-611.

[4] Henderson, D. (2015). A philosophical economist's case against a government-guaranteed basic income. The Independent Review, 19(4),489-502.

[5] Hodgson, G. (2006). What are institutions? Journal of Economic Issues, XL(1), 1-25.

[6] Hsieh, C.-T. (2003). Do consumers react to anticipated income changes? Evidence from the Alaska permanent fund. The American Economic Review, 93(1), 397-405.

[7] Keeley, M. (1987). The effects of experimental negative income tax programs on marital dissolution: Evidence from the Seattle and Denver income maintenance experiments. International Economic Review, 28(1), 241-257.

[8] Lavinas, L. (2006). From means-test schemes to basic income in Brazil: Exceptionality and paradox. International Social Security Review, 59(3), 103-125.

[9] Moffitt, R. (2003). The negative income tax and the evolution of U.S. welfare policy. Journal of Economic Perspectives, 17(3), 119-140.

[10] Munger, M. (2015a). Editor's introduction: The basic income debate. The Independent Review, 19(4), 485-488.

[11] Munger, M. (2015b). One and one-half cheers for a basic-income guarantee: We could do worse, and already have. The Independent Review, 19(4), 503513.

[12] North, D. (1992). Institutions and economic theory. The American Economist, 36(1), 3-6.

[13] Robins, P. (1985). A comparison of the labor supply findings from the four negative income tax experiments. The Journal of Human Resources, 20(4), 567-582.
[14] Salehi-Isfahani, D. (2014). Iran's subsidy reform from promise to disappointment. Policy Perspective, No. 13. Economic Research Forum.

[15] Smith, P. (1991). The politics of plenty: Investing natural resource revenues in Alberta and Alaska. Canadian Public Policy/Analyse De Politiques, 17(2), 139-154.

[16] Surdykowska, B. (2006). Dochód podstawowy. Polityka Spoteczna, 4(2006), 20-26.

[17] Varian, H. (2010). Intermediate microeconomics. A modern approach (8th ed). New York, NY, London, England: W. W. Norton \& Company.

[18] Voigt, S. (2013). How (not) to measure institutions. Journal of Institutional Economics, 9(1), 1-26.

[19] Williamson, O. (2000). The new institutional economics: Taking stock, looking ahead. Journal of Economic Literature, XXXVIII, 595-613.

[20] Zwolinski, M. (2015). Property rights, coercion, and the welfare state the libertarian case for a basic income for all. The Independent Review, 19(4), 515-529.

\section{Internet sources}

[1] Alaska Permanent Fund Corporation. (2018). On line. Access 17.04.2018. Retrieved from https:// web.archive.org/web/20141006103714/http:/ / www.apfc.org/home/Content/dividend/ dividendamounts.cfm.

[2] BBC. (2016). Switzerland's voters reject basicincome plan. On line. Access 01.11.2018. Retrieved from https:/ / www.bbc.com/news/world-europe-36454060.

[3] Bowman, D., Mallett, S., \& Cooney-O'Donoghue, D. (2017). Basic income: Trade-offs and bottom lines. Working Paper. Research Policy Centre, Brotherhood of St Laurence. On line. Access 22.04.2018. Retrieved from http://library.bsl.org. au/jspui/bitstream/1/10141/2/Bowman_etal_ Basic_income_2017.pdf.

[4] Goldsmith, S. (2010). The Alaska permanent fund dividend: A case study in implementation of a basic income guarantee. In 13th Basic Income Earth Network Congress, University of Sao Paulo. On line. Access 18.04.2018. Retrieved from https://scholarworks. alaska.edu/bitstream/handle/11122/4170/bien_ xiii_ak_pfd_lessons.pd f?sequence=1. 
[5] India Average Daily Wage Rate. (2018). On line. Access 23.04.2018. Retrieved from https:// tradingeconomics.com/india/wages.

[6] Iran, Islamic Republic. The World Bank. (2018). Data downloaded from the website. On line. Access 03.05.2018 Retrieved from https://data. worldbank.org/country/iran-islamic-rep.

[7] OECD. (2016a). Automation and independent work in a digital economy. Policy brief on the future of work, OECD Publishing. On line. Access 24.03.2018. Retrieved from http://www.oecd. org/employment/Automation-and-independentwork-in-a-digitaleconomy-2016.pdf.

[8] OECD. (2016b). Social expenditure update 2016: Social spending stays at historically high levels in many OECD countries. On line. Access 20.03.2018. Retrieved from http://www.oecd.org/els/soc/ OECD2016-Social-Expenditure-Update.pdf.

[9] OECD. (2017). Basic income as a policy option: Can it add up? Policy brief on the future of work, OECD Publishing. On line. Access 06.02.2018. Retrieved from https://www.oecd.org/els/emp/BasicIncome-Policy-Option-2017.pdf.

[10] OECD Data. (2018). Average wages. On line. Access 02.06.2018 Retrieved from https://data.oecd.org/ earnwage/average-wages.htm.

[11] Official Exchange Rate Iran. (2018). On line. Access 03.05.2018 Retrieved from https:/ / data.worldbank. org/indicator/PA.NUS.FCRF?locations=IR.

[12] Salehi-Isfahani, D., \& Mostafavi-Dehzooei, M. (2017). Cash transfers and labor supply: Evidence from a large-scale program in Iran. Economic Research Forum, Working Paper No. 1090. On line. Access 03.05.2018. Retrieved from http://erf.org. eg/publications/cash-transfers-and-labor-supplyevidence-from-a-large-scaleprogram-in-iran/.

[13] Standing, G. (2013a). India's experiment in basic income grants. Global Dialogue, 3(5). On line. Access 22.04.2018. Retrieved from http://globaldialogue. isa-sociology.org/indias-great-experiment-thetransformativepotential-of-basic-income-grants/

[14] Standing, G. (2013b). Unconditional basic income: Two pilots in Madhya Pradesh. A Background Note prepared for the Delhi Conference, May 30-31, 2013. On line. Access 22.04.2018. Retrieved from https:// www.guystanding.com/files/documents/Basic_ Income_Pilots_in_India_note_for_in augural.pdf. 